\title{
Effect of Bio-Control Agents on Yield, Yield Components and Root Rot Control in two Wheat Cultivars at New Valley Region
}

\author{
Mohamed YosseifMOUBARK', Montaser Fawzy ABDEL-MONAIM²* \\ ${ }^{1}$ Wheat Research Department, Field Crops Research Institute, A.R.C. Giza, Egypt \\ ${ }^{2}$ Plant Pathology Research Institute, A.R.C. Giza, Egypt; fowzy_2008@yahoo.com (*corresponding author)
}

\begin{abstract}
This study evaluated the effectiveness of applying the bioagents Bacillus subtilis (isolate BSM1), B. megaterium (isolate BMM5), Trichoderma viride (isolate TVM2) and T. harzianum (isolate THM4) for the control of rot root disease caused by Fusarium graminearum, Drechslera halodes and Rhizoctonia solani on two wheat cultivars ('Sakha 93' and 'Bani Suif 5') under greenhouse conditions. Moreover, their effect wheat growth and yield were also studied under field conditions. In vitro, all tested bioagents were significantly in the reduced redial growth of the pathogenic fungi. Trichoderma viride was active more than the other tested bioagents followed by T. harzianum, while $B$. subtilis was the least ones. Under greenhouse conditions, all tested bioagents were able to reduce significantly damping-off and root rot caused by the tested pathogens compared with control and increased fresh and dry weight of the survival plants when applied as soil or grain treatments however, there was variation among bioagent isolates effect on reduction of disease severity both application methods. Trichoderma viride and B. megaterium were recorded the highest effective in this respect compared with other tested bioagents. Under field conditions, analysis of variance and mean performance were estimated for four characters: grain yield $4.8 \mathrm{~m}^{-2}$, No. of spikes $\mathrm{m}^{-2}$, No. of kernels spike ${ }^{-1}$ and 1000-kernel weight. Significant mean squares were obtained for all studied characters between the seasons $(\mathrm{S})$, methods $(\mathrm{M}),(\mathrm{S})(\mathrm{M})$, treatments $(\mathrm{T}),(\mathrm{S})(\mathrm{T}),(\mathrm{M})(\mathrm{T})$ and $(\mathrm{S})(\mathrm{M})(\mathrm{T})$ for 'Sakha 93' cultivar and 'Bani Suif 5' cultivars except application methods and $(S)(M)$ for number of kernels spike ${ }^{-1}$ and 1000-kernel weight, respectively. While the treatments T. harzianum and $B$. megaterium were best treatments to increase grain yield, the treatments B. subtilis and T. harzianum were best treatments to increase number of spikes and the treatments B. subtilis and B. megaterium were best treatments to increase number of kernels for soil and grain application methods, respectively.
\end{abstract}

Keywords: bio-agents, root rot disease, wheat growth, yield and yield components

\section{Introduction}

Wheat is one of the most important feeding crops in Egypt and many other countries in the world. It is primarily grown as a food crop but the straw is also used for industrial products as feed for livestock. Wheat is subjected to relatively large number of diseases during its growing seasons which attack all plant parts causing serious losses in crop productivity (Bakr, 1997).

Root-rot diseases caused by soil-borne fungi are the most important wheat diseases. Several fungi were recorded as causal pathogens of root-rot diseases such as Fusarium graminearum, F. equiseti, F. solani, Drechslera halodes and Rhizoctonia solani (Asran and Eraky, 2011; Atef, 2008; Hashem and Hamada, 2002). These diseases remain prevalent because of the trends toward a higher frequency of cereals in the rotation, including, commonly, continuous cereals, and the use of less or no tillage.

Agricultural practices for management of soil borne pathogens in the field includes cultural practices, crop rotation, fungicide applications, methyl bromide fumigation, soil solarization and use of resistant or tolerant varieties. At present, no single method provides adequate control of soil borne diseases (Hausbek and Lamour, 2004). Using of chemicals to control soil borne pathogens causes several negative effects, such as: i) development of pathogen resistance, ii) hazards to humans, iii) damage to beneficial organisms and iv) environmental pollution. Moreover, many chemicals will be banned in near future. However, for sustainable production, pathogens still need to be controlled in order to ensure healthy plant establishment and growth (Gerhardson, 2002). Therefore, developments of various beneficial micro-organisms or biological control agents' methods are urgently needed in order to provide an alternative to chemical control. Among different biological approaches, use of the microbial antagonists like yeasts, fungi and bacteria could be promised, effectively, safely and eco-friendly in controlling many of soil borne pathogens (Gravel et al., 2004).

Many biological control agents such as Trichoderma spp. and Bacillus spp. could be effectively used in suppressing diseases caused by Fusarium spp. Drechslera halodes and Rhizoctonia solani as reported by many workers (Abdel- Monaim, 2010; Hashem and Hamada, 2002; Nourozian et al., 2006; Soleimani et al., 2005). Modes of action for beneficial micro-organisms include direct parasitism 
80

of plant pathogens, competition for space or nutrients, or production of antibiotics, enzymes or plant hormones (Lugtenberg et al., 2003). This led to promote plant growth during the growing season as reported by Mercier and Manker (2005). However, up to date, only a few antagonist microorganisms have been identified as potential, effective bio-control agents against soil borne pathogens (Spadaro and Gullino, 2005). Also, these bioagents due to significantly increased of seed germination and increased of plant growth in wheat and other many crops (El-Mohamedy et al., 2011; Riungu et al., 2008; Zafari, et al., 2008). The differences among genotypes, among methods and among treatments within all methods were significant for number of kernels spike-1, 1000-kernel weight and grain yield on the wheat (Moubarak, 2007). There were significant differences among the genotypes (Mahdy et al., 1996; Pawar et al., 1997).

The main objective of the present study was to evaluate the effectiveness of isolated micro-organisms from soil under New Valley governorate conditions as bio-control agents against the incidence of root-rot disease caused by Fusarium graminearum, Drechslera halodes and Rhizoctonia solani and its impact on vegetative growth, yield and yield components of two wheat cultivars under field conditions.

\section{Material and methods}

During 2008/2009 growing seasons, samples of wheat plants exhibiting root-rot were collected from different fields in New Valley Governorate. Samples were washed thoroughly with tap water. Small portions of the rootrot diseased samples were surface sterilized in $1 \%$ sodium hypochlorite solution for 5 minutes, rinsed in sterilized water and dried between folds of sterilized filter papers. The portions were placed on Potato Dextrose Agar (PDA) medium and incubated at $25 \pm 1^{\circ} \mathrm{C}$. The obtained fungal colonies were purified using single spore or hyphal tip techniques suggested by Dhingra and Sinclair (1985). Identification of the fungi detected was conducted according to Booth (1985) and Gilman (1998). Stock cultures were maintained on PDA slants and kept in a refrigerator at $5^{\circ} \mathrm{C}$ for further studies.

\section{Pathogenicity tests}

Groups of formalin-sterilized soil were separately infested with fungal inocula of four pathogenic fungi (15-days-old) grown on barley sand medium $(3 \%, \mathrm{w} / \mathrm{w})$, then slightly watered every other day for a week. Soil provided with the same amount of barley sand medium and free from fungal inocula were used as control. The infested and uninfested soils were packed in formalin-sterilized pots $(30 \mathrm{~cm}$ diam.). Wheat grain (cvs. 'Sakha 93' and 'Bani Suif 5') superficially sterilized with $1 \%$ sodium hypochlorite were sowed at the rate of 10 grains/pot. A set of 4 replicates were used for each fungus or check treatments. Percentages of damping-off determined after 30 days from planting. After 90 days from planting, wheat plants were removed from the soil, washed thoroughly to remove soil debris, root- rot were recorded as follows:

$0=$ roots without discoloration (no infection); $1=$ $1-20 \%$; $2=21-40 \% ; 3=41-75 \%$; $4=75-100 \%$ discoloration root mass and $5=$ completely dead plants include pre-or post emergence damping-off or old plants for each replicate. The mean of disease index (DI) and disease severity index (DSI) for each replicate was calculated by the formula suggested by Liu et al. (1995) was calculates as follows:

$$
D S I=\frac{\sum d}{d \max \times n} \times 100
$$

where as: $\mathrm{d}$ is the disease rating of each plant, $\mathrm{d}$ max is the maximum disease rating and $\mathrm{n}$ is the total number of plants examined for each replicate.

\section{Efficacy of antagonistic bioagents against pathogenic fungi in vitro \\ Bacillus subtilis (isolate BSM1), B. megaterium (isolate} BMM5), Trichoderma viride (isolate TVM2) and T. harzianum (isolate THM4), were used in these experiments as bioagents against root_rot diseases on wheat were obtained from Plant Pathology Research Department, New Valley Agric. Res. Station.

Antagonism of Trichoderma viride, T. harzianum on Fusarium graminearum, Drechslera halodes and Rhizoctonia solani, the causal pathogens of root-rot on wheat plants, was studied by dual culture technique (Rama et al., 2000). A mycelial disc (7 mm diameter), obtained from the peripheral region of 5 days old cultures tested pathogenic and bioagent fungi were placed simultaneously on the periphery, about $1 \mathrm{~cm}$ from the edges of the Petridishes ( $9 \mathrm{~cm}$ diameter) content PDA medium at opposite sides. While in each isolate of $B$. megaterium and B. subtilis was streaked individually at one side on PDA medium in plates and incubated for 24 hrs., then one disc $(7 \mathrm{~mm}$ in diameter) of any pathogenic isolate was placed on the opposite side (Kaur et al., 2007). The Petri dishes containing the PDA medium inoculated with the tested pathogens alone served as control. All plates were incubated at $28^{\circ} \mathrm{C}$ and measurements were taken after 5 days. At the end of incubation period, radial growth was measured. The percentage inhibition growth of tested pathogens in presence of bioagents was calculated. Mycelial growth inhibition was calculated by using the formula:

Mycelial growth inhibition (\%) $=100(\mathrm{C}-\mathrm{T} / \mathrm{C})$

where $\mathrm{C}=$ growth in control and $\mathrm{T}=$ growth in treatment.

\section{Efficacy of grain and soil treatments with some bioagents under greenhouse and field conditions}

\section{Production of bioagents inocula used for grain and soil treatments}

Antagonistic bacterial inocula were produced as described by Landa et al. (2001). Bacterial concentration in the suspension was adjusted to proximately $5 \times 10^{8}$ cells $\mathrm{ml}^{-1}$ by measuring absorbance at $600 \mathrm{~nm}$ in a spectropho- 
tometer and using standard curves for each bacterial isolate. While inocula of antagonistic fungi were prepared as described by Sallam Nashwa et al. (2008). The fungal suspension was adjusted to $3 \times 10^{7} \mathrm{cfu} \mathrm{ml}^{-1}$, using haemocytometre for each isolate. The bacterial and fungal suspension was used for grain coating and soil drenching.

\section{Under greenhouse conditions}

Formalin-sterilized soil were inoculated with the highly pathogenic isolated fungi i.e. $R$. solani, F. graminearum and $D$. halodes individually at rate $3 \%$ then irrigated and left for 7 days. The infested pots were divided into two groups, the first group planted with wheat grains soaked in suspension of bioagent isolates for $6 \mathrm{~h}$. before sowing and the second groups were drenching with $50 \mathrm{ml}$ of bio agents isolates then planting with untreated wheat grains. Ten grains were sown in pots which were infested with the pathogens. Also untreated grains were sown in pots infested with the tested pathogens to serve as a control. All treatments were in 4 replicates and arranged in complete randomized design.

\section{Under field conditions}

The present study was carried out at the New Valley Agricultural Research Station by Wheat Research Department, during two successive growing seasons, 2009/2010 and 2010/2011. Two wheat (Tritium spp.) cultivars were used to study the bio-control agents. The name and pedigree of these cultivars are presented in (Tab. 1) In the growing seasons, the two wheat cultivars were grown for evaluation in a randomized complete blocks design (RCBD) with four replications. Each plot was planted in eight rows;

Tab. 1. The name, origin and pedigree of two wheat cultivars

\begin{tabular}{ccccc}
\hline No. & Cultivars & Origin & Scientific name & Pedigree \\
\hline 1 & 'Sakha 93' & Egypt & Triticum aestivum L. & $\begin{array}{c}\text { Sakha 92/ } \\
\text { TR 810328. }\end{array}$ \\
2 & 'Bani Suif5' & Egypt & Triticum durum L. & $\begin{array}{c}\text { Dipper-2/ } \\
\text { Bushen-3. }\end{array}$ \\
\hline
\end{tabular}

four meter long, $20 \mathrm{~cm}$ apart. The recommended cultural practices were applied from sowing to harvesting. Data for the studied characters recorded on six internal rows.

The studied characters were grain yield $4.8 \mathrm{~m}^{-2}$ (Kg.), number of spikes $\mathrm{m}^{-2}$, number of kernels spike-1 and 1000-kernel weight (g.). The obtained data were analyzed to estimate better methods and treatments of using biocontrol agents.

\section{Statistical analysis}

The Least Significant Differences (L.S.D.) test at 5\% level of probability, according to Steel and Torrie (1980) was used to compare among means.

\section{Results and discussion}

Isolation trials from diseased roots of wheat plants resulted in five pathogenic fungi, i.e. Fusarium graminearum, F. equiseti, F. solani, Drechslera halodes and Rhizoctonia solani.

\section{Pathogenicity tests}

Pathogenicity of isolated fungi was tested on two wheat cultivars ('Sakha 93' and 'Bani Suif 5'). Data in Tab. 2 indicate that all the tested fungi significantly caused damping-off and root- rot in both wheat cultivars subsequently, decreased the percentages of healthy survival plants compared with the check treatment. Rhizoctonia solani was the most pathogenic fungi as they recorded percentage damping-off (60 and 50\%) and 26.8 and 23\% root rot in both cultivars, respectively followed by $D$. halodes where caused 50 and $40 \%$ damping-off and 25.8 and $20.4 \%$ On the contrary, $F$. solani and F. equiseti were the least pathogenic ones recording the lowest percentages of these criteria. It was also observed that the percentages of damping-off in all tested fungi were higher than those of root rot. These results are in harmony with those reported by Asran and Eraky (2011), Atef (2008) and Hashem and Hamada (2002).

Tab. 2. Pathogenic ability of four soil borne fungi on damping-off and root rot severity of wheat plants under greenhouse conditions

\begin{tabular}{|c|c|c|c|c|c|c|}
\hline \multirow{3}{*}{ Treatments } & \multicolumn{6}{|c|}{ Cultivars } \\
\hline & \multicolumn{3}{|c|}{ 'Sakha 93' } & \multicolumn{3}{|c|}{ 'Bani Suif 5' } \\
\hline & $\begin{array}{c}\text { Damping-off } \\
\%\end{array}$ & $\begin{array}{c}\text { Root rot } \\
\%\end{array}$ & $\begin{array}{c}\text { Survival plants } \\
\%\end{array}$ & $\begin{array}{c}\text { Damping-off } \\
\%\end{array}$ & $\begin{array}{c}\text { Root rot } \\
\%\end{array}$ & $\begin{array}{c}\text { Survival plant } \\
\% s\end{array}$ \\
\hline F.graminearum & 40 & 30.0 & 30.0 & 35 & 22.4 & 42.6 \\
\hline F. equiseti & 25 & 18.2 & 56.8 & 20 & 14.8 & 65.2 \\
\hline F. solani & 20 & 15.4 & 64.6 & 20 & 10.0 & 70.0 \\
\hline D. halodes & 50 & 25.8 & 24.2 & 40 & 20.4 & 39.6 \\
\hline R. solani & 60 & 26.8 & 13.2 & 50 & 23.0 & 27.0 \\
\hline LSD at 0.05 & \multicolumn{2}{|c|}{ Damping-off } & \multicolumn{2}{|c|}{ Root rot } & \multicolumn{2}{|c|}{ Survival plants } \\
\hline Treatments (A) & \multicolumn{2}{|c|}{3.70} & \multicolumn{2}{|c|}{3.20} & \multicolumn{2}{|c|}{5.78} \\
\hline Cultivars (B) & \multicolumn{2}{|c|}{2.33} & \multicolumn{2}{|c|}{2.03} & \multicolumn{2}{|c|}{3.65} \\
\hline Interaction $(\mathrm{AxB})$ & \multicolumn{2}{|c|}{5.23} & \multicolumn{2}{|c|}{ ns } & \multicolumn{2}{|c|}{ ns } \\
\hline
\end{tabular}


82

\section{Efficacy of Antagonistic Bioagents Against Pathogenic} Fungi in Vitro

Bacillus subtilis, B. megaterium, T. viride and T. harzianum, strains were evaluated for antagonistic effect against $F$. graminearum, $D$. halodes and $R$. solani on Petri dishes containing PDA medium. Tab. 3 show that the bioagent strains succeeded in reducing the radial growth of the tested pathogenic fungi. Trichoderma viride was active more than the other tested bioagents for reducing the radial growth of fungi. The percent inhibition of radial growth of tested fungi, F. graminearum (67.7\%), D. halodes (74.0\%), and $R$. solani (59.5\%) were reduced by T. viride which grown over the colonies of all three pathogens. On the other hand Trichoderma isolates were effective more than Bacillus isolates in inhibition of redial growth of all the tested fungi and the greatest reduction occurring in $D$. halodes (63.07\%) followed by $F$. graminearum (54.77\%), while $R$. solani less affected ones (50.07\%). The growth inhibition of wheat root rot fungi by dual culture in this study could be due to its fast growing nature, secretions of armful extra-cellular compounds like antibiotics, cell wall degrading enzymes such as $\beta-1,3$ gluconase, endochitinase and chitinase enzymes which degrade the cell wall leading to lyses of mycelium of the pathogen and mycoparasitism in dual culture as found with other fungi (Lugtenberg et al., 2003; Rahman et al., 2010; Riungu et al., 2008).

\section{Efficacy of grain and soil treatments with some bioagent isolates}

\section{Greenhouse experiments}

In the seed coating and soil treatment tests, all the tested bioagents were able to reduce significantly damping-off and root rot caused by $F$ graminearum, $D$. halodes and $R$. solani compared with control, however, there was variation among bioagent isolates effect on reduction of disease severity both soil and seed application methods and both cultivates (Tab. 4 A, B, C). B. megaterium and T. viride recorded the highest reduction in damping-off and root rot severity caused by the tested fungi, while soil and/or grain treatments with $B$. subtilis and T. harzianum gave the lowest redaction for these diseases in both cultivars.

Concerning the method of applications, it is cleared that there were a significant differences among method of applications. The highest significant values for suppressing
Fusarium, Drechslera and Rhizoctonia root rots incidence on wheat plants were recorded with soil treatment in all cases. Also, there were significant variation among both cultivars; however cv. 'Sakha 93' was more susceptible than cv. 'Bani Suif 5' in all cases. On the other hand, the obtained data show that all of the soil and grain application treatments increased significant the fresh and dry weight of the survival wheat plants compared with control, but there was difference among their effect in this regard. The maximum fresh and dry weight obtained in $B$. megaterium followed by $T$. viride. While the lowest increased of fresh and dry weight of survival wheat plants were recorded in case of B. subtilis application. On the other hand, soil application treatment improved the fresh and dry weights of wheat were more than grain application method in all cases. Also, cv. 'Bani Suif 5' gave fresh and dry weights high than cv. 'Sakha 93' in most cases.

Generally, B. megaterium and T. viride recorded the highest reduction of damping-off, root rot and increased fresh and dry weight of survival wheat plants especially in soil application method.

The obtained results are in good accordance with previous studies which have been concluded that Trichoderma spp. and Bacillus spp. can effectively protect many plant species against root rot diseases (Abdel- Monaim, 2010; Atef, 2008; Hashem and Hamada, 2002; Nourozian et al., 2006; Soleimani et al., 2005). According to Harman (2001) natural factors limiting the number of soil borne pathogens occur through a combination of antagonism by other soil fungi and bacteria, natural release of antibiotics from other bacteria and fungi, and by competitive exclusion of habitat in the root zone or rhizosphere.

The mechanism of Trichoderma and Bacillus action on pathogens may be by attacking and binding the pathogenic organisms by sugar linkage and begins to secrete extracellular protease and lipase (Soleimani et al., 2005; Zaghloul et al., 2007), produce siderophores and hydrogen cyanide (Soleimani et al., 2005), produce of secondary metabolites such as Phenazine -1-Carboxilic acid (PCA), 2,4-Pyrrolnitrin, Oomycin (Knudsen et al., 1995).

\section{Under field conditions}

Mean squares for all studied characters in (Tab. 5), showed significant differences between the seasons $(S)$, methods $(\mathrm{M}),(\mathrm{S})(\mathrm{M})$, treatments $(\mathrm{T}),(\mathrm{S})(\mathrm{T}),(\mathrm{M})(\mathrm{T})$ Tab. 3. Inhibitory effect of some bio-against isolates on mycelial growth of wheat pathogenic fungi

\begin{tabular}{ccccc}
\hline \multirow{2}{*}{ Treatments } & \multicolumn{4}{c}{ Mycelial growth inhibition (\%) } \\
\cline { 2 - 5 } & F. graminearum & D. halodes & R. solani & Mean \\
\hline B. subtilis & 39.2 & 53.1 & 41.8 & 44.70 \\
B. megaterium & 52.0 & 58.5 & 48.1 & 52.87 \\
T. viride & 67.7 & 74.0 & 59.5 & 67.07 \\
T. harzianum & 60.2 & 66.7 & 50.9 & 59.27 \\
Mean & 54.77 & 63.07 & 50.07 & - \\
\hline \multirow{2}{*}{ LSD at 0.05} & Treatments (A) & Pathogenic fungi (B) & Interaction (AxB) & 6.85 \\
\hline
\end{tabular}


Tab. 4A. Effect of soil drenching, wheat grain treatment with different bioagents on damping-off and root rot diseases, fresh and dry weight plant $^{-1}$ under artificial infection with Fusarium graminearum under greenhouse conditions

\begin{tabular}{|c|c|c|c|c|c|c|c|c|c|}
\hline \multirow[b]{2}{*}{ Treatments } & \multirow[b]{2}{*}{$\begin{array}{l}\text { Application } \\
\text { methods }\end{array}$} & \multicolumn{4}{|c|}{ 'Sakha 93' } & \multicolumn{4}{|c|}{ 'Bani Suif 5' } \\
\hline & & $\begin{array}{c}\text { Damping- } \\
\text { off } \\
\% \\
\end{array}$ & $\begin{array}{c}\text { Root rot } \\
\%\end{array}$ & $\begin{array}{c}\text { Fresh weight } \\
\left(\text { g plant }^{-1}\right)\end{array}$ & $\begin{array}{c}\text { Dry } \\
\text { weight } \\
\left(\text { g plant }^{-1}\right)\end{array}$ & $\begin{array}{c}\text { Damping- } \\
\text { off } \\
\% \\
\end{array}$ & $\begin{array}{c}\text { Root rot } \\
\%\end{array}$ & $\begin{array}{c}\text { Fresh } \\
\text { weight } \\
\left(\text { g plant }^{-1}\right)\end{array}$ & $\begin{array}{c}\text { Dry } \\
\text { weight } \\
\left(\text { g plant }^{-1}\right)\end{array}$ \\
\hline \multirow{2}{*}{ B. subtilis } & Soil & 20 & 14.0 & 3.161 & 0.691 & 15 & 10.0 & 3.422 & 0.725 \\
\hline & Grain & 30 & 16.4 & 2.481 & 0.524 & 25 & 12.8 & 2.235 & 0.473 \\
\hline \multirow{2}{*}{ B. megaterium } & Soil & 5 & 6.6 & 4.583 & 0.972 & 10 & 5.2 & 4.25 & 0.907 \\
\hline & Grain & 10 & 8.0 & 4.028 & 0.872 & 15 & 6.8 & 3.657 & 0.796 \\
\hline \multirow{2}{*}{ T. viride } & Soil & 15 & 7.6 & 4.209 & 0.923 & 5 & 4.5 & 3.969 & 0.795 \\
\hline & Grain & 15 & 9.4 & 3.412 & 0.731 & 10 & 6.0 & 3.414 & 0.699 \\
\hline \multirow{2}{*}{ T. harzianum } & Soil & 20 & 12.4 & 3.800 & 0.786 & 15 & 9.0 & 3.55 & 0.77 \\
\hline & Grain & 25 & 13.6 & 3.078 & 0.622 & 25 & 10.6 & 2.914 & 0.621 \\
\hline \multicolumn{2}{|c|}{ Control } & 45 & 33.6 & 1.333 & 0.277 & 35 & 25.4 & 1.182 & 0.251 \\
\hline \multicolumn{2}{|c|}{ LSD at 0.05} & \multicolumn{2}{|c|}{ Damping-off } & \multicolumn{2}{|c|}{ Root rot } & \multicolumn{2}{|c|}{ Fresh weight } & \multicolumn{2}{|c|}{ Dry weight } \\
\hline \multicolumn{2}{|c|}{ Treatments $(\mathrm{A})$} & \multicolumn{2}{|c|}{1.71} & \multicolumn{2}{|c|}{1.20} & \multicolumn{2}{|c|}{0.177} & \multicolumn{2}{|c|}{0.057} \\
\hline \multicolumn{2}{|c|}{ Application methods (B) } & \multicolumn{2}{|c|}{${ }^{*}$} & \multicolumn{2}{|c|}{${ }^{*}$} & \multicolumn{2}{|c|}{ * } & \multicolumn{2}{|c|}{ * } \\
\hline \multicolumn{2}{|c|}{ Cultivars $(\mathrm{C})$} & \multicolumn{2}{|c|}{ * } & \multicolumn{2}{|c|}{${ }^{*}$} & \multicolumn{2}{|c|}{ * } & \multicolumn{2}{|c|}{$*$} \\
\hline \multicolumn{2}{|c|}{ Interaction $(\mathrm{AxBxC})$} & \multicolumn{2}{|c|}{ ns } & \multicolumn{2}{|c|}{2.55} & \multicolumn{2}{|c|}{ ns } & \multicolumn{2}{|c|}{0.111} \\
\hline
\end{tabular}

Tab. 4B. Effect of soil drenching, wheat grain treatment with different bioagents on damping-off and root rot diseases, fresh and dry weight plant $^{-1}$ under artificial infection with Drechslera halodes under greenhouse conditions

\begin{tabular}{|c|c|c|c|c|c|c|c|c|c|}
\hline \multirow[b]{2}{*}{ Treatments } & \multirow[b]{2}{*}{$\begin{array}{l}\text { Application } \\
\text { methods }\end{array}$} & \multicolumn{4}{|c|}{ 'Sakha 93' } & \multicolumn{4}{|c|}{ 'Bani Suif 5' } \\
\hline & & $\begin{array}{c}\text { Damping- } \\
\text { off } \\
\% \\
\end{array}$ & $\begin{array}{c}\text { Root rot } \\
\%\end{array}$ & $\begin{array}{c}\text { Fresh weight } \\
\left(\text { g plant }^{-1}\right)\end{array}$ & $\begin{array}{c}\text { Dry } \\
\text { weight } \\
\left(\text { g plant }^{-1}\right)\end{array}$ & $\begin{array}{c}\text { Damping- } \\
\text { off } \\
\% \\
\end{array}$ & $\begin{array}{c}\text { Root rot } \\
\%\end{array}$ & $\begin{array}{c}\text { Fresh } \\
\text { weight } \\
\left(\text { g plant }^{-1}\right)\end{array}$ & $\begin{array}{c}\text { Dry } \\
\text { weight } \\
\left(\text { g plant }^{-1}\right)\end{array}$ \\
\hline \multirow{2}{*}{ B. subtilis } & Soil & 20 & 12 & 3.142 & 0.674 & 20 & 10.8 & 2.916 & 0.634 \\
\hline & Grain & 30 & 13.6 & 2.627 & 0.557 & 25 & 13.0 & 2.014 & 0.431 \\
\hline \multirow{2}{*}{ B. megaterium } & Soil & 5 & 6.8 & 5.092 & 1.088 & 5 & 5.8 & 4.071 & 0.833 \\
\hline & Grain & 15 & 8.2 & 4.022 & 0.863 & 10 & 6.2 & 3.214 & 0.643 \\
\hline \multirow{2}{*}{ T. viride } & Soil & 5 & 10.6 & 3.613 & 0.738 & 5 & 7.6 & 3.208 & 0.628 \\
\hline & Grain & 10 & 12.0 & 3.429 & 0.702 & 5 & 9.4 & 2.814 & 0.603 \\
\hline \multirow{2}{*}{ T. harzianum } & Soil & 25 & 19.8 & 3.633 & 0.731 & 15 & 16.6 & 3.029 & 0.617 \\
\hline & Grain & 35 & 22.2 & 3.240 & 0.672 & 25 & 19.8 & 2.492 & 0.541 \\
\hline \multicolumn{2}{|c|}{ Control } & 50 & 28.4 & 1.037 & 0.209 & 40 & 24.6 & 0.805 & 0.171 \\
\hline \multicolumn{2}{|c|}{ LSD at 0.05} & \multicolumn{2}{|c|}{ Damping-off } & \multicolumn{2}{|c|}{ Root rot } & \multicolumn{2}{|c|}{ Fresh weight } & \multicolumn{2}{|c|}{ Dry weight } \\
\hline \multicolumn{2}{|c|}{ Treatments (A) } & \multicolumn{2}{|c|}{2.45} & \multicolumn{2}{|c|}{1.28} & \multicolumn{2}{|c|}{0.177} & \multicolumn{2}{|c|}{0.048} \\
\hline \multicolumn{2}{|c|}{ Application methods (B) } & \multicolumn{2}{|c|}{ * } & \multicolumn{2}{|c|}{${ }^{*}$} & \multicolumn{2}{|c|}{ * } & \multicolumn{2}{|c|}{ * } \\
\hline \multicolumn{2}{|c|}{ Cultivars $(\mathrm{C})$} & \multicolumn{2}{|c|}{${ }^{*}$} & \multicolumn{2}{|c|}{$*$} & \multicolumn{2}{|c|}{${ }^{*}$} & \multicolumn{2}{|c|}{ * } \\
\hline \multicolumn{2}{|c|}{ Interaction $(\mathrm{AxBxC})$} & \multicolumn{2}{|c|}{4.89} & \multicolumn{2}{|c|}{2.56} & \multicolumn{2}{|c|}{0.352} & \multicolumn{2}{|c|}{0.097} \\
\hline
\end{tabular}

and (S) (M) (T) for 'Sakha 93' cultivar, except methods and $(S)(M)$ for number of kernels spike ${ }^{-1}$. These results are confirmed with those obtained by Mahdy et al. (1996), Moubarak (2007) and Pawar et al. (1997).

Mean squares for all studied characters in (Tab. 6), showed significant differences between the seasons $(\mathrm{S})$, methods $(\mathrm{M}),(\mathrm{S})(\mathrm{M})$, treatments $(\mathrm{T}),(\mathrm{S})(\mathrm{T}),(\mathrm{M})(\mathrm{T})$ and $(S)(M)(T)$ for 'Bani Suif 5' cultivar, except methods and (S) (M) for 1000-kernel weight. These results are confirmed with those obtained by Mahdy et al. (1996), Moubarak (2007) and Pawar et al. (1997).

The results illustrated in (Tab. 7 and 8), showed that, in soil application method, the treatments T. harzianum,
B. subtilis, B. subtilis and B. megaterium had highest values for grain yield, number of spikes $\mathrm{m}^{-2}$, number of kernels spike $^{-1}$ and 1000-kernel weight in the two seasons, respectively, while in grain application method, the treatments B. megaterium, T. harzianum, B. megaterium and B. megaterium had highest values for grain yield, number of spikes $\mathrm{m}^{-2}$, number of kernels spike ${ }^{-1}$ and 1000-kernel weight in the two seasons, respectively. From the previous results, it could be concluded that, the treatments T. harzianum and $B$. megaterium were best treatments to increase grain yield, the treatments $B$. subtilis and T. harzianum were best treatments to increase number of spikes and the treatments $B$. subtilis and $B$. megaterium were best treatments to increase 
84

Tab. 4C. Effect of soil drenching, wheat grain treatment with different bioagents on damping-off and root rot diseases, fresh and dry weight plant ${ }^{-1}$ under artificial infection with Rhizoctonia solani under greenhouse conditions

\begin{tabular}{|c|c|c|c|c|c|c|c|c|c|}
\hline \multirow[b]{2}{*}{ Treatments } & \multirow[b]{2}{*}{$\begin{array}{l}\text { Application } \\
\text { methods }\end{array}$} & \multicolumn{4}{|c|}{ 'Sakha 93' } & \multicolumn{4}{|c|}{ 'Bani Suif 5' } \\
\hline & & $\begin{array}{c}\text { Damping- } \\
\text { off } \\
\% \\
\end{array}$ & $\begin{array}{c}\text { Root rot } \\
\%\end{array}$ & $\begin{array}{l}\text { Fresh weight } \\
\left(\text { g plant }^{-1}\right)\end{array}$ & $\begin{array}{c}\text { Dry } \\
\text { weight } \\
\left(\text { g plant }^{-1}\right)\end{array}$ & $\begin{array}{c}\text { Damping- } \\
\text { off } \\
\% \\
\end{array}$ & $\begin{array}{c}\text { Root rot } \\
\%\end{array}$ & $\begin{array}{c}\text { Fresh } \\
\text { weight } \\
\left(\text { g plant }^{-1}\right)\end{array}$ & $\begin{array}{c}\text { Dry } \\
\text { weight } \\
\left(\text { g plant }^{-1}\right)\end{array}$ \\
\hline \multirow{2}{*}{ B. subtilis } & Soil & 20 & 14.2 & 2.345 & 0.512 & 15 & 10.0 & 2.267 & 0.501 \\
\hline & Grain & 25 & 17.4 & 1.958 & 0.405 & 15 & 13.8 & 2.001 & 0.402 \\
\hline \multirow{2}{*}{ B. megaterium } & Soil & 10 & 7.6 & 3.900 & 0.809 & 10 & 6.0 & 3.100 & 0.668 \\
\hline & Grain & 15 & 8.2 & 3.409 & 0.735 & 10 & 8.0 & 2.069 & 0.443 \\
\hline \multirow{2}{*}{ T. viride } & Soil & 5 & 5.6 & 2.967 & 0.602 & 5 & 4.6 & 2.933 & 0.625 \\
\hline & Grain & 10 & 6.4 & 2.491 & 0.542 & 5 & 6.0 & 2.725 & 0.579 \\
\hline \multirow{2}{*}{ T. barzianum } & Soil & 25 & 16.4 & 2.817 & 0.600 & 20 & 13.6 & 2.521 & 0.512 \\
\hline & Grain & 35 & 22.6 & 2.183 & 0.452 & 30 & 15.6 & 2.055 & 0.439 \\
\hline \multicolumn{2}{|c|}{ Control } & 55 & 30.4 & 1.038 & 0.219 & 45 & 23.2 & 1.058 & 0.229 \\
\hline \multicolumn{2}{|c|}{ LSD at 0.05} & \multicolumn{2}{|c|}{ Damping-off } & \multicolumn{2}{|c|}{ Root rot } & \multicolumn{2}{|c|}{ Fresh weight } & \multicolumn{2}{|c|}{ Dry weight } \\
\hline \multicolumn{2}{|c|}{ Treatments (A) } & \multicolumn{2}{|c|}{2.00} & \multicolumn{2}{|c|}{1.50} & \multicolumn{2}{|c|}{0.229} & \multicolumn{2}{|c|}{0.051} \\
\hline \multicolumn{2}{|c|}{ Application methods (B) } & \multicolumn{2}{|c|}{ * } & \multicolumn{2}{|c|}{ * } & \multicolumn{2}{|c|}{ * } & \multicolumn{2}{|c|}{$*$} \\
\hline \multicolumn{2}{|c|}{ Cultivars $(\mathrm{C})$} & \multicolumn{2}{|c|}{$*$} & \multicolumn{2}{|c|}{ * } & \multicolumn{2}{|c|}{${ }^{*}$} & \multicolumn{2}{|c|}{$*$} \\
\hline \multicolumn{2}{|c|}{ Interaction $(\mathrm{AxBxC})$} & \multicolumn{2}{|c|}{3.98} & \multicolumn{2}{|c|}{$\mathrm{ns}$} & \multicolumn{2}{|c|}{0.460} & \multicolumn{2}{|c|}{$\mathrm{ns}$} \\
\hline
\end{tabular}

Tab. 5. Mean square analysis of four characters for 'Sakha 93' bread wheat cultivar using bio-control agents by soil and grain methods in 2009/2010 and 2010/2011 seasons

\begin{tabular}{cccccc}
\hline \multirow{2}{*}{ S.O.V } & \multirow{2}{*}{ d.f. } & \multicolumn{4}{c}{ Mean squares } \\
\cline { 3 - 6 } & & Grain yield $4.8 \mathrm{~m}^{-2}$ & No. of spikes m ${ }^{-2}$ & No. of kernels spike ${ }^{-1}$ & 1000 -kernel weight \\
\hline Replications & 3 & 0.004 & 34.533 & 13.933 & 0.635 \\
Seasons (S) & 1 & $9.716^{*}$ & $12152.450^{*}$ & $2121.800^{*}$ & $1570.878^{*}$ \\
\hline Methods (M) & 1 & $0.021^{*}$ & $6265.800^{*}$ & 0.200 & $24.753^{*}$ \\
SM & 1 & $0.036^{*}$ & $2184.050^{*}$ & 7.200 & $110.215^{*}$ \\
\hline Treatments (T) & 4 & $0.388^{*}$ & $4976.513^{*}$ & $122.856^{*}$ & $298.386^{*}$ \\
ST & 4 & $0.120^{*}$ & $892.825^{*}$ & $42.581^{*}$ & $11.924^{*}$ \\
MT & 4 & $0.201^{*}$ & $5423.737^{*}$ & $308.606^{*}$ & $40.884^{*}$ \\
SMT & 4 & $0.023^{*}$ & $926.800^{*}$ & $14.231^{*}$ & $17.766^{*}$ \\
\hline Error & 57 & 0.004 & 46.130 & 3.065 & 2.101 \\
\hline
\end{tabular}

${ }^{*}$ Significant at $5 \%$ probability

Tab. 6. Mean square analysis of four characters for 'Bani Suif 5' durum wheat cultivar using bio-control agents by soil and grain methods in 2009/2010 and 2010/2011 seasons

\begin{tabular}{cccccc}
\hline \multirow{2}{*}{ S.O.V } & \multirow{2}{*}{ d.f. } & \multicolumn{4}{c}{ Mean squares } \\
\cline { 3 - 6 } & & Grain yield $4.8 \mathrm{~m}^{-2}$ & No. of spikes m & No. of kernels spike ${ }^{-1}$ & 1000 -kernel weight \\
\hline Replications & 3 & 0.007 & 41.233 & 1.512 & 2.204 \\
Seasons $(\mathrm{S})$ & 1 & $3.113^{*}$ & $9159.200^{*}$ & $1453.513^{*}$ & $1553.203^{*}$ \\
\hline Methods (M) & 1 & $0.021^{*}$ & $8946.450^{*}$ & $32.513^{*}$ & 0.001 \\
SM & 1 & $0.031^{*}$ & $530.450^{*}$ & $35.112^{*}$ & 0.435 \\
\hline Treatments $(\mathrm{T})$ & 4 & $0.520^{*}$ & $4649.019^{*}$ & $371.294^{*}$ & $119.963^{*}$ \\
\hline ST & 4 & $0.032^{*}$ & $1000.544^{*}$ & $15.919^{*}$ & $7.977^{*}$ \\
MT & 4 & $0.315^{*}$ & $5239.794^{*}$ & $383.106^{*}$ & $3.414^{*}$ \\
SMT & 4 & $0.018^{*}$ & $1127.294^{*}$ & $64.206^{*}$ & $23.208^{*}$ \\
\hline Error & 57 & 0.004 & 45.996 & 3.153 & 1.616 \\
\hline
\end{tabular}

${ }^{*}$ Significant at $5 \%$ probability

number of kernels for soil application method and grain application method, respectively. The obtained results are in harmony with that obtained by Riungu et al. (2008) and Zafari et al. (2008) on wheat. All these workers reported that using beneficial micro-organisms as biocontrol agents let to enhancement of plant growth parameters. Such enhancement may be due to induce plant resistance (De Meyer et al., 1998), produce extracellular enzymes and 
Tab. 7. Effect of bio-control against on grain yield $\left(\mathrm{Kg} 4.8 \mathrm{~m}^{-2}\right)$, No. of spikes $\mathrm{m}^{-2}$, kernels spikes ${ }^{-1}$ and 1000-kernel weight for

'Sakha 93' bread wheat cultivar in 2009/2010 and 2010/2011 seasons

\begin{tabular}{|c|c|c|c|c|c|c|}
\hline Seasons & Treatments & Application methods & Grain yield $4.8 \mathrm{~m}^{-2}$ & No. of spikes $\mathrm{m}^{-2}$ & No. of kernels spike ${ }^{-1}$ & 1000-kernel weight \\
\hline \multirow{9}{*}{$2009 / 2010$} & \multirow{2}{*}{ B. subtilis } & Soil & 1.73 & 349.50 & 62.25 & 50.63 \\
\hline & & Grain & 1.66 & 330.50 & 56.25 & 45.08 \\
\hline & \multirow{2}{*}{ B. megaterium } & Soil & 1.62 & 237.50 & 46.50 & 57.10 \\
\hline & & Grain & 1.89 & 347.75 & 61.00 & 49.45 \\
\hline & \multirow{2}{*}{ T. viride } & Soil & 1.68 & 309.00 & 55.75 & 42.93 \\
\hline & & Grain & 1.70 & 316.25 & 48.25 & 45.95 \\
\hline & \multirow{2}{*}{ T. harzianum } & Soil & 1.86 & 326.00 & 57.75 & 53.53 \\
\hline & & Grain & 1.69 & 368.25 & 54.25 & 46.40 \\
\hline & \multicolumn{2}{|c|}{ Control } & 1.59 & 305.00 & 59.25 & 44.95 \\
\hline \multirow{9}{*}{$2010 / 2011$} & \multirow{2}{*}{ B. subtilis } & Soil & 2.44 & 359.00 & 74.25 & 56.88 \\
\hline & & Grain & 2.12 & 336.75 & 67.50 & 55.15 \\
\hline & \multirow{2}{*}{ B. megaterium } & Soil & 2.46 & 322.75 & 60.25 & 64.03 \\
\hline & & Grain & 2.86 & 358.75 & 76.25 & 64.03 \\
\hline & \multirow{2}{*}{ T. viride } & Soil & 2.41 & 342.50 & 63.25 & 48.30 \\
\hline & & Grain & 2.23 & 337.50 & 63.25 & 53.08 \\
\hline & \multirow{2}{*}{ T. harzianum } & Soil & 2.76 & 351.25 & 66.75 & 57.85 \\
\hline & & Grain & 2.49 & 378.75 & 61.00 & 60.98 \\
\hline & \multicolumn{2}{|c|}{ Control } & 2.10 & 327.00 & 65.50 & 54.65 \\
\hline \multicolumn{3}{|c|}{ LSD at 0.05} & Grain yield $4.8 \mathrm{~m}^{-2}$ & No. of spikes $\mathrm{m}^{-2}$ & No. of kernels spike $e^{-1}$ & 1000-kernel weight \\
\hline \multicolumn{3}{|c|}{ Seasons (S) and Methods (M) } & 0.057 & 6.075 & 1.566 & 1.297 \\
\hline \multicolumn{3}{|c|}{$(\mathrm{S})(\mathrm{M})$} & 0.08 & 8.591 & 2.215 & 1.833 \\
\hline \multicolumn{3}{|c|}{ Treatments $(\mathrm{T})$} & 0.057 & 6.075 & 1.566 & 1.296 \\
\hline \multicolumn{3}{|c|}{$(\mathrm{S})(\mathrm{T})$ and $(\mathrm{M})(\mathrm{T})$} & 0.081 & 8.592 & 2.215 & 1.833 \\
\hline \multicolumn{3}{|c|}{$(\mathrm{S})(\mathrm{M})(\mathrm{T})$} & 0.114 & 12.15 & 3.132 & 2.593 \\
\hline
\end{tabular}

Tab. 8. Effect of bio-control against on grain yield $\left(\mathrm{Kg} 4.8 \mathrm{~m}^{-2}\right)$, No. of spikes $\mathrm{m}^{-2}$, kernels spikes ${ }^{-1}$ and 1000-kernel weight for 'Bani Suif 5 ' durum wheat cultivar in 2009/2010 and 2010/2011 seasons

\begin{tabular}{|c|c|c|c|c|c|c|}
\hline Seasons & Treatments & Application methods & Grain yield $4.8 \mathrm{~m}^{-2}$ & No. of spikes $\mathrm{m}^{-2}$ & No. of kernels spike ${ }^{-1}$ & 1000-kernel weight \\
\hline \multirow{9}{*}{$2009 / 2010$} & \multirow{2}{*}{ B. subtilis } & Soil & 2.99 & 325.50 & 62.25 & 53.23 \\
\hline & & Grain & 2.83 & 287.75 & 62.00 & 52.60 \\
\hline & \multirow{2}{*}{ B. megaterium } & Soil & 2.81 & 289.75 & 47.25 & 60.20 \\
\hline & & Grain & 3.08 & 280.00 & 67.50 & 58.43 \\
\hline & \multirow{2}{*}{ T. viride } & Soil & 2.88 & 310.50 & 59.00 & 51.00 \\
\hline & & Grain & 2.77 & 269.00 & 49.25 & 53.88 \\
\hline & \multirow{2}{*}{ T. harzianum } & Soil & 3.34 & 286.00 & 65.75 & 55.68 \\
\hline & & Grain & 2.99 & 295.00 & 55.25 & 55.90 \\
\hline & \multicolumn{2}{|c|}{ Control } & 2.72 & 250.50 & 50.25 & 56.65 \\
\hline \multirow{9}{*}{$2010 / 2011$} & \multirow{2}{*}{ B. subtilis } & Soil & 3.28 & 350.00 & 73.25 & 61.15 \\
\hline & & Grain & 3.10 & 256.25 & 69.25 & 64.60 \\
\hline & \multirow{2}{*}{ B. megaterium } & Soil & 3.18 & 287.50 & 59.25 & 65.83 \\
\hline & & Grain & 3.76 & 311.75 & 75.25 & 67.30 \\
\hline & \multirow{2}{*}{ T. viride } & Soil & 3.26 & 357.50 & 62.25 & 62.88 \\
\hline & & Grain & 3.19 & 288.75 & 67.25 & 57.65 \\
\hline & \multirow{2}{*}{ T. harzianum } & Soil & 3.72 & 317.50 & 68.25 & 64.48 \\
\hline & & Grain & 3.42 & 324.25 & 64.25 & 64.00 \\
\hline & \multicolumn{2}{|c|}{ Control } & 3.08 & 282.50 & 57.50 & 67.23 \\
\hline \multicolumn{3}{|c|}{ LSD at 0.05} & Grain yield $4.8 \mathrm{~m}^{-2}$ & No. of spikes $\mathrm{m}^{-2}$ & No. of kernels spike ${ }^{-1}$ & 1000-kernel weight \\
\hline \multicolumn{3}{|c|}{ Seasons (S) and Methods (M) } & 0.054 & 6.066 & 1.588 & 1.137 \\
\hline \multicolumn{3}{|c|}{$(\mathrm{S})(\mathrm{M})$} & 0.077 & 8.579 & 2.246 & 1.608 \\
\hline \multicolumn{3}{|c|}{ Treatments $(\mathrm{T})$} & 0.054 & 6.066 & 1.588 & 1.137 \\
\hline \multicolumn{3}{|c|}{$(\mathrm{S})(\mathrm{T})$ and $(\mathrm{M})(\mathrm{T})$} & 0.077 & 8.579 & 2.246 & 1.608 \\
\hline \multicolumn{3}{|c|}{$(\mathrm{S})(\mathrm{M})(\mathrm{T})$} & 0.108 & 12.133 & 3.177 & 2.274 \\
\hline
\end{tabular}


86

antifungal or antibiotics, which decrease biotic stress on plant, and produce growth promoters substances (Szczech and Shoda, 2004). In addition, Egamberdiyeva (2007) hypothesized that there are several mechanisms by which rhizosphere bacteria may stimulate plant growth, such as production of plant growth substances, nitrogen fixation, phytohormones, vitamins, solublizing minerals besides, their role in direct inhibition of pathogen growth and suppression of diseases caused micro-organisms and increased of plant growth and yield.

\section{Conclusions}

Specific rhizobacterial and rhizofungal agents can influence disease suppression and could be considered as apart of disease control strategy like integrated pest management which offers a successful approach for the deployment of both agro-chemicals and biocontrol agents. Also, this study suggest that simultaneous screening of rhizobacteria and rhizofungi for growth and yield promotion under field experiment is a good tool to select effective rhizobacteria and rhizofungi for biofertilizer development biotechnology.

The treatments $T$. harzianum and B. megaterium were best treatments to increase grain yield, the treatments $B$. subtilis and T. harzianum were best treatments to increase number of spikes and the treatments $B$. subtilis and $B$. megaterium were best treatments to increase number of kernels for soil application method and grain application method, respectively.

\section{References}

Abdel-Monaim MF (2010). Integrated management of damping-off, root and/or stem rot diseases of chickpea with sowing date, host resistance and bioagents. Egypt J Phytopathol 38(1-2):45-61.

Asran MR, Eraky Amal MI (2011). Aggressiveness of certain Fusarium graminearum isolates on wheat seedling and relation with their Trichothecence production. Plant Pathology J 10(1):36-41.

Atef Nagwa M (2008). Bacillus subtilits and Trichoderma harzianum as wheat inoculants for biocontrol of Rhizoctonia solani. Austr J Basic Appl Sci 2(4):1411-1417.

Bakr DW (1997). Studies on some Root Rots of Wheat. M. Sc. Thesis, Faculty Agriculture Assuit University, Assiut, Egypt.

Booth C (1985). The genus Fusarium. Kew, Surrey Commonwealth Mycological Institute, $2^{\text {nd }} E d ., 237 \mathrm{p}$.

De Meyer G, Bigirimana J, Elad Y, Höfte M (1998). Induced systemic resistance in Trichoderma harzianum T39 biocontrol of Botrytis cinerea. Eur J Plant Pathol 104:279-286.

Dhingra OD, Sinclair JB (1985). Basic Plant Pathology Methods. CRC, Boca Raton, Florida, USA.

Egamberdiyeva D (2007). The effect of plant growth promoting bacteria on growth and nutrient uptake of maize in two different soils. Appl Soil Ecol 36:184-189.

El-Mohamedy RSR, Abd El-Samad EH, Habib Hoda AM, Fath El-Bab TSh (2001). Effect of using bio-control agents on growth, yield, head quality and root rot control in broccoli plants grown under greenhouse conditions. Internat J Academic Res 3(2):71-80.

Gerhardson B (2002). Biological substitute for pesticides. Trends Biotech 20:338-343.

Gilman JC (1998). A manual of soil fungi: Iowa. State. Univ. Press. Iowe, U.S.A.

Gravel V, Martinez C, Antoun H, Tweddell RJ (2004). Evaluation of antagonistic microorganisms as bio-control agents of root rot (Pythium ultimum) of greenhouse tomatoes in rock wool. Can J Plant Pathol 26:152-159.

Harman GE (2001). Trichoderma spp., including $T$. harzianum, T. viride, T. koningii, T. hamatum and other spp. Deuteromycetes, Moniliales (asexual classification system). In: Weeden CR, Shelton AM, Hoffman MP (Eds.). Biological Control: A Guide to Natural Enemies in North America. Cornell University, USA.

Hashem M, Hamada Afaf M (2002). Evaluation of two biologically active compounds for control of wheat root rot and its causal pathogens. Microbiol 30(4):233-239.

Hausbek MK, Lamour KH (2004). Phytophthora capsici on vegetable crops: research progress and management challenges. Plant Disease 88:1292-1303.

Kaur R, Singh RS, Alabouvette C (2007). Antagonistic activity of selected isolates of fluorescent Pseudomonas against Fusarium oxysporum f. sp. ciceri. Asian J Plant Sci 6(3):446454.

Knudsen IMB, Hockenhull J, Jensen DF (1995). Biocontrol of seedling diseases of barley and wheat caused by Fusarium culmorum and Bipolaris sorokiniana: Effects of selected fungal antagonists on growth and yield components. Plant Pathol 44:467-477.

Landa BB, Navas-Cortés JA, Hervás A, Jiménez-Díaz RM (2001). Influence of temperature and inoculum density of Fusarium oxysporum f. sp. ciceris on suppression of Fusarium wilt of chickpea by rhizosphere bacteria. Phytopathol 91:807-816

Liu L, Kloepper JW, Tuzun S (1995). Introduction of systemic resistance in cucumber against Fusarium wilt by plant growth-promoting rhizobacteria. Phytopathol 85:695-698.

Lugtenberg BJJ, Bloemberg GV, Woeng CA, Thomas FC (2003). Phenazines and their role in bio-control by Pseudomonas bacteria. New Phytol 153:503-523.

Mahdy EE, Ismail AA, Kheiralla KA (1996). The relative merits of selection index and pedigree selection in improving grain yield of spring wheat. Assiut J Agric Sci 27:17-33.

Mercier J, Manker DC (2005). Bio-control of soil borne diseases and plant growth enhancement in greenhouse soilless mix by the volatile-producing fungus Muscodor albus. Crop Protect 24:355-362. 
Moubarak MYGh (2007). Efficiency of Some Breeding Methodologies on Some Bread Wheat Populations under New Valley Conditions. PhD. Thesis, Minia Univ. Egypt.

Nourozian J, Etebarian HR, Khodakaramian G (2006). Biological control of Fusarium graminearum on wheat by antagonistic bacteria. Nutraceutic Funct Food 28(1):29-38.

Pawar IS, Yunus M, Karwasra SS, Prabalee S (1997). Use of single spike selection procedure in wheat improvement. Haryana Agric Univ J Res 27:167-169.

Rahman T, Ahmed AU, Islam MR, Hosen MI (2010). Physiological study and both in vitro and in vivo antifungal activities against Stemphylium botrysum caused Stemphylium blight disease in lentil (Lens culinaris). Plant Pathol J 9(4):179-187.

Rama B, Raju M, Krishna Murthy KVM (2000). Efficacy of Trichoderma spp. In the management of collar rot of groundnut caused by Aspergillus niger Van Teighem. Ind J Plant Prot 28:197-199.

Riungu GM, Muthomi JW, Narla RD, Wagacha JM, Gathumbi JK (2008). Management of Fusarium head blight of wheat and deoxynivalenol accumulation using antagonistic microorganisms. Plant Pathol J 7:13-19.

Sallam Nashwa MA, Abo-Elyousr KAM, Hassan MA (2008). Evaluation of Trichoderma species as biocontrol agent for damping-off and wilt diseases of Phaseolus vulgaris L. and efficacy of suggested formula. Egypt J Phytopathol 36(12):81-93.
Soleimani MJ, Shamsbakhsh M, Taghavi M, Kazemi Sh (2005). Biological control of stem and root rot of wheat caused by Bipolaris spp. by using antagonistic bacteria, fluorescent Pseudomonas and Bacillus sp. J Biological Sci 5(3):347353.

Spadaro D, Gullino ML (2005). Improving the efficacy of biocontrol agents against soil borne pathogens. Crop Protect 24:601-613.

Steel RGD, Torri JH (1980). Principles and procedures of statistical biometrical approaches $2^{\text {nd }}$ ED Mc Graw Hill Book company, New York. USA.

Szczech M, Shoda M (2004). Bio-control of Rhizoctonia damping-off of tomato by Bacillus subtilis combined with Burkholderia cepacia. J Phytopathol 152:549-556.

Zafari D, Koushki MM, Bazgir E (2008). Biocontrol evaluation of take-all disease by Trichoderma screened isolates. African J of Biotechn 7:3653-3659.

Zaghloul RA, Hanafy Ehsan A, Neweigy NA, Khalifa Neamat A (2007). Application of biofertilization and biological control for tomato production. $12^{\text {th }}$ Conference of Microbiology; Cairo, Egypt, 198-212 p. 